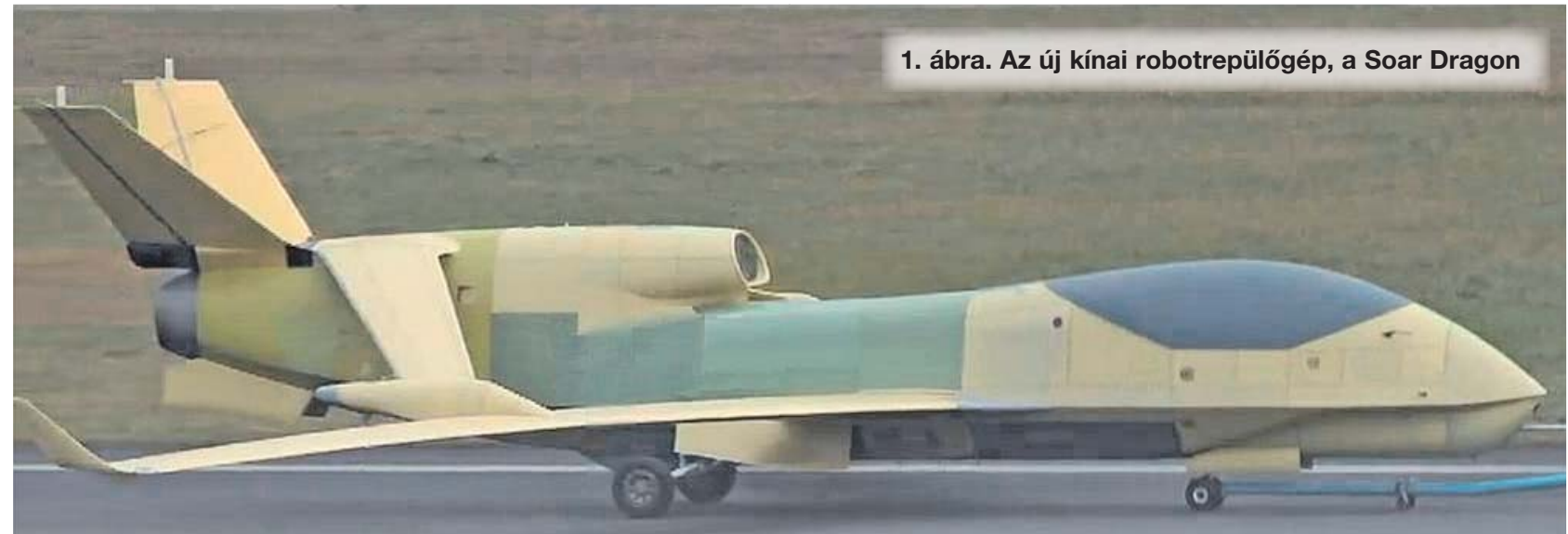

Sárhidai Gyula*

\title{
Az új hadászati kategóriájú Soar Dragon kínai robotrepülőgép
}

2 017. augusztus 24-én egy földfelszínt fotózó, de polgári műhold felvételén - 8 darab J-10-es vadászgép, 2 darab J-7A vadászbombázó, 2 darab J-11-es (SzU-30MKK) nehéz vadászgép, egy Mi-17-es helikopter és egy II-76-os szállítógép mellett - megjelent 3 darab EA-03 jelü kínai robotrepülőgép.

A felvétel a Tibeti Autonóm Tartomány Shigatse Peace nevű repülőteréről készült, közel az indiai határhoz. Ez a

\section{2. ábra. A Soar Dragon prototípusa, még egyetlen függőleges} vezérsíkkal (B.B.)

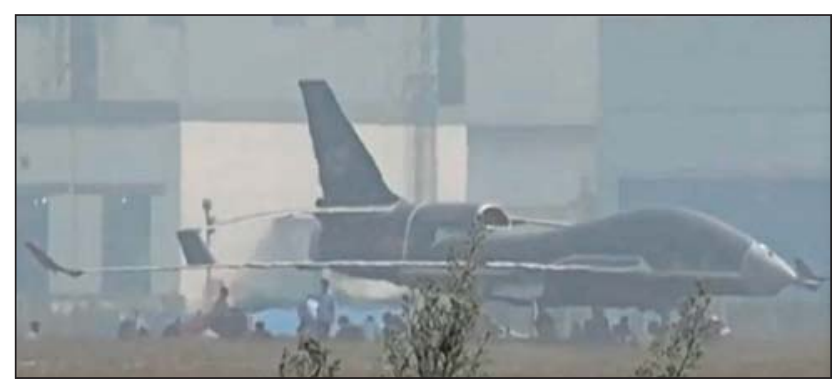

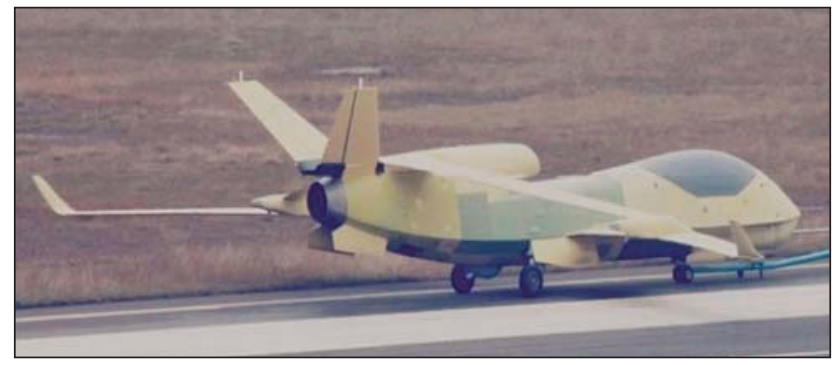

3. ábra. A drón hátulról: jól látható az utánégető nélküli (egyes források szerint Kujcsou WP-13-as szovjet Tumanszkij R-13-as) sugárhajtómű kiömlönyílása (B.B.)

bázis a Doklam-Fennsíkon, a Bhután-Kína-India határszögletben kb. 250 km-re fekszik a kínai-indiai állásoktól. Erről annyi ismert, hogy 2017. augusztus 28-án - három hónapos készenléti állapot után - Kína és India megegyezett, hogy csapataikat visszavonják a határtól. Mindenesetre a kínai hadsereg (PLA) egy utat épít kb. 10 km-re az indiai haderő állásaitól. Lehetséges, hogy a felderítő robotrepülőgépek a helyzet ellenőrzésére vannak jelen.
ÖSSZEFOGLALÁS: A Kínai Népköztársaság új fejlesztésű, EA-03 UAV típusú felderítő robotrepülőgépe a Xianlong (Szárnyaló Sárkány, az angol irodalomban Soar Dragon) nevet kapta. A drónt a Kujcsou (Guizhou) Repülőgépgyár építi Anshuanban lévő üzemében. A típusról semmiféle hivatalos kínai katonai, vagy ipari közlemény nem jelent meg. A nyugati források elsősorban légi felderítési, illetve ellenséges hajók elleni küldetésre szánt szerepről tesznek emlitést.

KULCSSZAVAK: Kínai Népköztársaság, felderítő robotrepülőgép, EA-03 UAV, Soar Dragon
ABSTRACT: The newly developed EA-03 UAV reconnaissance robot aircraft of the People's Republic of China was named Xianlong (Soar Dragon in the English technical literature). The drone is being manufactured by the Guizhou Aviation Aircraft Co Ltd at its factory in Anshan. No official Chinese military or industrial statement on the type was published yet. According to Western sources, this UAV will be built for reconnaissance and anti-ship missions.

KEY WORDS: People's Republic of China, reconnaissance UAV, EA-03 UAV, Soar Dragon

Mérnök, Haditechnikai Intézet volt főelőadó, Haditechnika folyóirat korábbi szerkesztő, ORCID: 0000-0002-2008-7997 


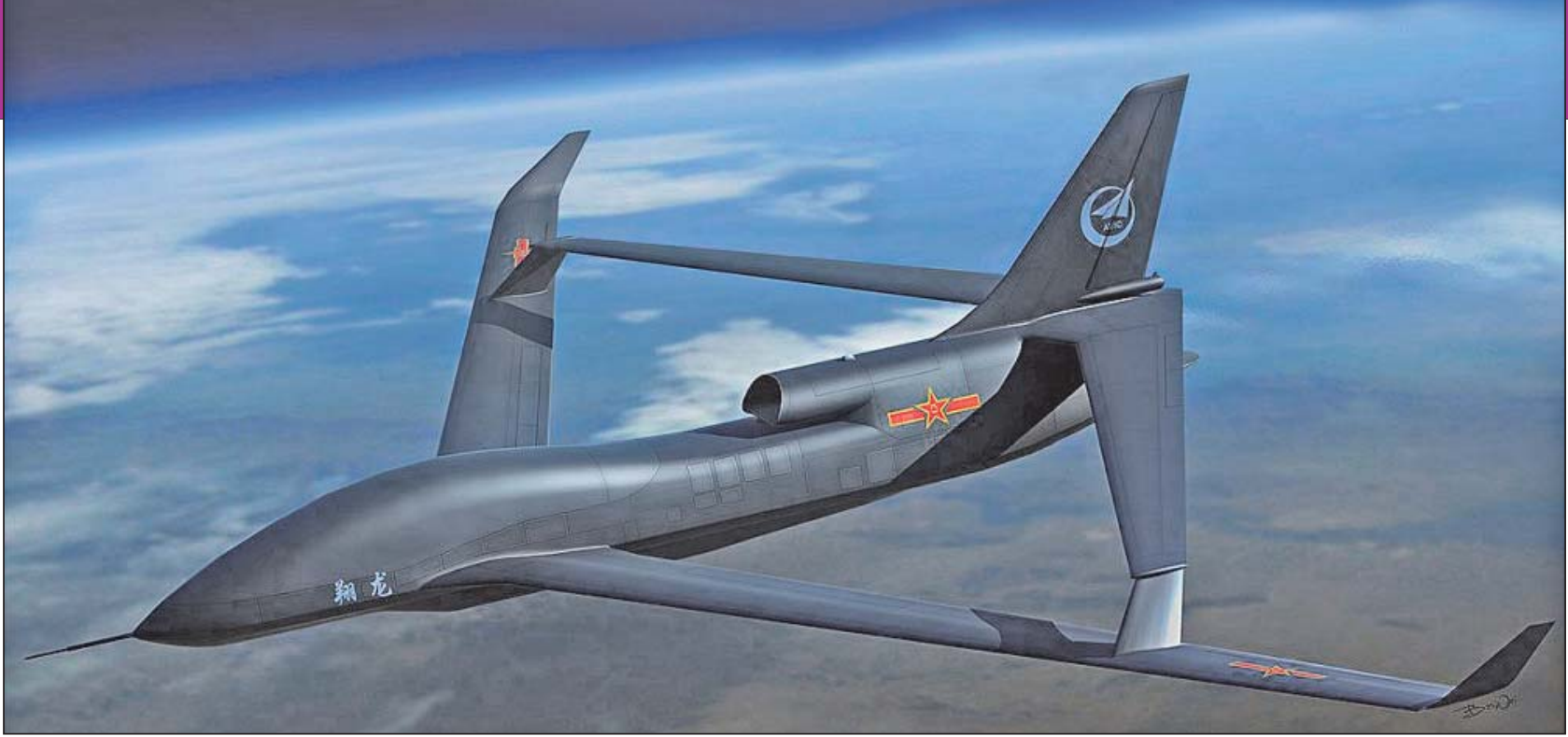

4. ábra. A drón eredetileg tervezett kialakítása egy grafikán

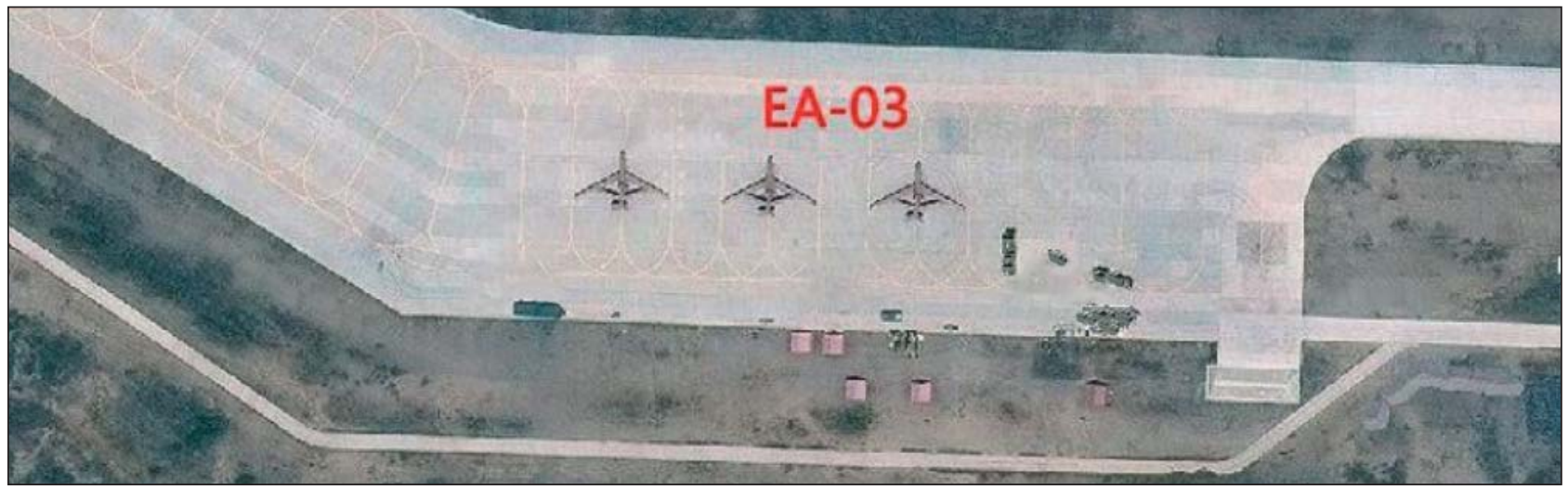

5. ábra. Soar Dragonok a tibeti támaszponton, a 2017. 08. 24-i müholdfelvétel kinagyított részén

Nyomban keresni kezdték az előzményeket, hogy mit tudnak erről a típusról. Egy 2016 júliusában készült képen látható volt a GAC (Guizhou Aircraft Corporation) végszerelő csarnokában, egy JL-9-es sugárhajtású kiképzőgép mögött, 3 darab EA-03 UAV repülőgép a gyártás különböző fázisaiban.

Az új gép neve Xianlong (Szárnyaló Sárkány, az angol irodalomban Soar Dragon) és a Kujcsou (Guizhou) Repülőgépgyár építi az Anshuanban lévő üzemében. A típusról semmiféle hivatalos kínai katonai, vagy ipari közlemény nem jelent meg, a keringő adatok csupán találgatások.

A mühold felbocsátói a kamerarendszer és a röppályamagasság pontos ismeretében ki tudják számítani a gép külső méreteit, de egyebet nem.

Kína egy párperces filmet mutatott be, amelyen egy kész példányt, még alapozó sárga színben kivontatnak a gyári csarnokból. Adatok itt sem szerepelnek, de a képek emblémája mutatja, hogy eredeti felvételekről van szó.

Egy korai előzmény ismert. Az 4. ábrán látható modellt a 2006-os chengdui repülési és űrhajózási kiállításon mutatták be, minden közelebbi információ nélkül. A modellről

\section{6. ábra. A gyári példány, vontatás közben}

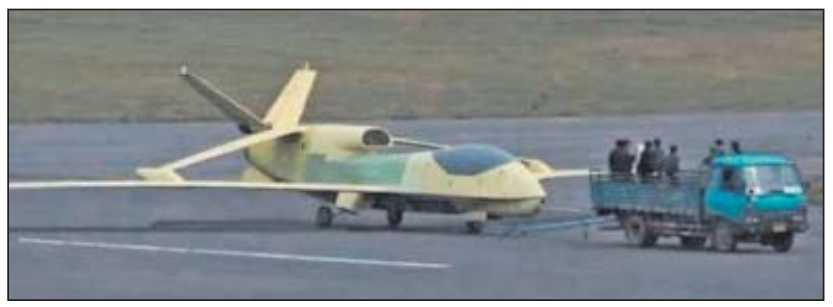

készült fotót utólag montírozták. Jól látható, hogy a szárnyak és vízszintes vezérsíkok rombusz elrendezése már az akkori terveken megvolt, a függőleges vezérsík változott és V-formáció lett.

A gép futóműve egy dupla ballonos orrkerék és két egyballonos főfutó, a törzsbe húzzák be őket. A sárkány minden valószínűség szerint kompozitos műanyag elemekből áll, hogy a szárnyak belsejében van-e üzemanyagtartály, nem ismert. A magassági és csűrőkormányok működtetése nyilván megoldott.

Szembetűnő, hogy a nagy fesztávú vízszintes vezérsíkok előrenyilazottak, törővégeik hozzá vannak kapcsolva az erősen hátranyilazott szárnyak középső szekciójához. Így ezek is felhajtóerőt termelő felületek.

A törzsön felül egy, két oldalán egy-egy szürke színű panel látható, amely nyilván antennákat és elektronikus berendezéseket takar. A szárnyvégek törővége (winglet) felhajtott, a zavaró áramlás csökkentése érdekében.

A nyugati források elsősorban felderítő és EW feladatkörben számítanak rá, de szenzorjaival lehetséges ellenséges hajók felderítése és célkoordináták közlése a hajó elleni ballisztikus rakéták és robotrepülőgépek számára. Lehetséges zavaró és fegyverhordozó alkalmazása is.

\section{FORRÁSOK}

Popular Science, 2017. 11. 07.;

Def. Post, 2017. 11. 07.;

AeroTech, 2017.11.02.;

Hajdú Ferenc - Sárhidai Gyula: Hadászati és hadművelet robotrepülőgépek, Zrínyi, 2007. 